\title{
Bioremediation of Spent Engine Oil Contaminated Soil by Using Fungus, Penicillium sp.
}

\author{
Umana, Etim Johnson ${ }^{1},{ }^{*}$ Akwaji, Patrick Ishoro ${ }^{1}$ \\ and Markson, Aniedi-Abasi Akpan ${ }^{1}$ \\ ${ }^{1}$ Department of Botany, University of Calabar, Calabar, Cross River State, Nigeria. \\ *akwajiisnever@yahoo.com
}

Keywords: Bioremediation, spent engine oil, Penicillium sp, soil.

\begin{abstract}
This study investigated the ability of Penicillium $s p$. to bio-remediate spent engine oil contaminated soil both in vitro and in vivo. In the in vitro assay, mycelium of a seven day old culture of Penicillium sp. grown on Sabouraud Dextrose Agar (SDA) was punched out using a $0.5 \mathrm{~mm}$ Cork borer and inoculated on the centre of Petri dishes containing the spent and unspent engine oil and incubated for seven days and daily reading of the mycelia growth obtained using a metre rule. For the in vivo assay, soil received 0 (control), 20/180, 40/360, 60/540, 80/720 and $100 \mathrm{ml} / 900 \mathrm{~mm}$ concentrations/treatments (inoculation with mycelium of Penicillium $s p$.). Seeds of Telfeira occidentalis was sown on the soil and assessed for growth performance (plant height, leaf area (using a metre rule) and leaf count (number of leaves) for 7, 14, 21 and 28 Days after Planting (DAP). Results of the in vitro assay showed a significant increase $(\mathrm{p}<0.05)$ in the growth diameter of Penicillium sp. relative to control. Results of the in vivo assay showed that spent engine oil had no significant effect $(\mathrm{p}<0.05)$ on the growth performance of $T$. occidentalis at 7, 14, 21 and 28 DAP and on fresh and dry weight (g) 28 DAP relative to control. After 28 days of plant growth, the added spent engine oil was no longer detected. The plant began producing pods 61 DAP. This study showed that Penicillium sp. can biodegrade hydrocarbons present in spent engine oil and as such is a good tool for bioremediation.
\end{abstract}

\section{Introduction}

Bioremediation is a process that uses microorganisms such as fungi (mycoremediation) and green plants to remove contaminants such as oil from the environment, which could be in-situ or exsitu [1]. Mycoremediation refers to the use of fungi to clean contaminated soil [2]. According to [3], to achieve a successful mycoremediation process, fungi must grow and survive in soils contaminated with oil. In oil contaminated sites, mycoremediation can be applied as a final clean up measure to further breakdown residual hydrocarbons as well as to improve soil quality [4]. Mycoremediation is a viable method that can be used to bio-remediate areas contaminated with pollutants because it is affordable and environmentally friendly [5].

According to Achuba et al. [6] and Wang et al. [7] spent engine oil is a brown-to-black liquid and a mixture of various chemicals such as aliphatic hydrocarbons, aromatic hydrocarbons, polychlorinated biphenyls, chlorodibenzofurans, lubricative additives, decomposition products and heavy metal contaminants that come from engine parts as they wear out.

Similarly, Anoliefo et al. [8] reported that there are large amounts of hydrocarbons present in spent engine oil such as the highly toxic polycyclic aromatic hydrocarbon (PAH). Furthermore, Wei et al. [9] reported that spent engine oil in soil creates conditions that are unhealthy for plant growth such as heavy metal toxicity to poor aeration of soil. Odjegba and Sadiq [10] reported that contamination from spent engine oil is a major environmental challenge and is more widespread than crude oil pollution. According to Meinz [11] spent engine oil as a petroleum product contains potentially hazardous chemicals, especially the polycyclic aromatic hydrocarbons (PAHs), heavy metals and chemicals additives such as amines, phenol and benzenes while Ikhajiagbe and Anoliefo [12] reported that spent engine oil pollution can affect a vast area when they are carried by run-off during rainfall to nearby farms and Fetzer [13] reported that chemicals found in oil contaminated 
soil can cause a reduction in the level of available plant nutrients and a rise to a toxic level of elements such as manganese.

Over the years, automobiles repairs and maintenance activities have been carried out by auto mechanics at the Uyo Mechanic Village located at Afa Ofot in Uyo Metropolis of Akwa Ibom State, Nigeria. The site is well known as a farming area where crops consumed around Uyo Metropolis, Ediene-Abak, Abak and Ikot Ekpene are harvested. In recent times, complaints by farmers have been received concerning loss in produce due to land pollution as a result of spent engine oil released by the auto-mechanics. In view of this and based on the menace caused by oil pollution on plants, a research on how to reclaim the farmland ex-situ was carried out using mycelium of Penicillium $s p$, a fungus also found within these areas. The objective of the present study therefore, was to test Penicillium $s p$. for its ability to bio-remediate spent engine oil contaminated soils both in vitro and in vivo.

\section{Materials and Methods}

\section{Sources of Materials}

Matured dry fluted pumpkin (Telfeira occidentalis) seeds were obtained in Uyo main market in Uyo Metropolis, while spent engine oil was obtained from the Uyo Mechanic Village, Afa Ofot in Uyo Metropolis, both in Akwa Ibom State, Nigeria. Soil sample (Sandy-loam) was obtained from Afa Ofot, Abak Road in Uyo Metropolis, Akwa Ibom State, Nigeria for soil analysis. The study was carried out in the Laboratory and Green House of the Department of Botany, University of Calabar, Calabar, Cross River State, Nigeria.

\section{Source of fungus and morphological identification}

The fungus used in this research work was isolated from spent engine oil contaminated soil collected from the Uyo Mechanic Village, Uyo Metropolis, Akwa Ibom State, Nigeria using Direct Plate Method (DPM). Approximately $2 \mathrm{~g}$ of the spent engine oil contaminated soil was placed on Sabouraud Dextrose Agar (SDA) in Petri dishes. Four (4) sections were inoculated per Petri dish. The plates were incubated at $28 \pm 1{ }^{\circ} \mathrm{C}$ until fungus growth was noticed. After 5 days, the isolate was sub-cultured on freshly prepared SDA to obtain pure culture. Isolated fungus was microscopically (Olympus optical, Phillipines) identified as far as possible using the identification guides of the International Mycological Institute, Kew [14].

\section{In vitro assay}

$2 \mathrm{ml}$ of spent and unspent engine oil was first poured into different Petri dishes $(90 \mathrm{~mm})$ using sterile syringe, and with a sterilized No.2 cork borer of $5.5 \mathrm{~mm}$ in diameter, a disc of the matured culture was punched out and inoculated at the centre of plates and incubated at room temperature of $(28 \pm 1 \mathrm{oC})$ for 7 days. As a control, the fungus was inoculated on Potato Dextrose Agar instead of spent and unspent engine oil. Three (3) control plates were prepared for each sample. Measurement of the mycelium growth diameter was obtained daily for seven days using a calliper and metre rule [15].

\section{In vivo assay}

\section{Soil analysis}

Sandy-loam soil was collected and analysed at the Research Laboratory of the Department of Soil Science, University of Calabar, Calabar, Cross River State, Nigeria for percentage moisture, $\mathrm{pH}$, total Nitrogen $\mathrm{N}$ (determined using Kjedahl's method followed by spectrophotometry procedure), organic carbon (determined by oxidation with $\mathrm{K}_{2} \mathrm{Cr}_{2} \mathrm{O}_{7}$ [16], Available phosphorus $\mathrm{P}$, calcium $\mathrm{Ca}$, and magnesium $\mathrm{Mg}$ (determined using the method of [17], Potassium $\mathrm{K}$ (determined using flame photometry). 


\section{Soil sterilization}

Soil sterilization was conducted in the Department of Botany green house, University of Calabar, Nigeria under mean temperature of $27^{\circ} \mathrm{C}$. The top soil collected at $0-45 \mathrm{~cm}$ depth were heat sterilized in a cut covered metal drum using firewood at $100^{\circ} \mathrm{C}$ for 20 minutes and allowed to cool. The sterilized soil was dispensed into polyethylene bags.

\section{Soil treatment/Soil inoculation}

Polyethylene bags were filled with about 5 kilogram $(5 \mathrm{~kg})$ of the sandy-loam soil treated with $20,40,60,80$ and $100 \mathrm{ml}$ concentration of spent engine oil. The treatments were replicated thrice and laid out (Experimental Design) in a Complete Randomized Design (CRD). Soil inoculation was carried out using the methods of [18]. 180mm (2 Petri dishes) containing seven day old mycelium of Penicillium sp. grown on PDA was dissolved in $100 \mathrm{ml}$ of distilled water and inoculated into the soil treated with $20 \mathrm{ml}$ of spent engine oil, while $360 \mathrm{~mm}$ (4 Petri dishes) was dissolved in $100 \mathrm{ml}$ of distilled water and inoculated into the soil treated with $40 \mathrm{ml}$ of spent engine oil. Soil treated with $60 \mathrm{ml}$ of spent engine oil was inoculated with $540 \mathrm{~mm}$ (6 Petri dishes) dissolved in $100 \mathrm{ml}$ of distilled water, while $80 \mathrm{ml}$ was inoculated with $720 \mathrm{~mm}$ ( 8 Petri dishes) dissolved in $100 \mathrm{ml}$ of distilled water and $100 \mathrm{ml}$ treatment was inoculated with $900 \mathrm{~mm}$ (10 Petri dishes) of seven day old mycelium of Penicillium $s p$. dissolved in $100 \mathrm{ml}$ of distilled water. Soil, treatment (spent engine oil) and mycelium of Penicillium sp. were thoroughly mixed before planting with Telfairia occidentalis seeds.

\section{Planting of T. occidentalis}

Three to four seeds of $T$. occidentalis were sown in polyethylene bags containing spent engine oil polluted soil and inoculated with mycelium of Penicillium sp. After seed emergence, the plant was reduced to two stands per bag. As the plants grew, growth parameters such as plant height (PH), leaf area (LA), and number of leaves (NL) was collected at 7 Days after Planting (DAP), 14 (DAP), 21 (DAP) and 28 (DAP). Fresh weight (FW) and Dry weight (DW) were collected at 28 (DAP) in three replicates. Frequency of watering was morning and evening.

\section{Statistical analysis}

Data obtained in this research work were analysed by one way analysis of variance (ANOVA) using IBM SPSS ver. 21 and sample means were compared using Least Significant Difference (LSD) and Duncan multiple range test to obtain significant data.

\section{Results}

\section{Isolated fungus}

Penicillium sp. (Figure 1) was isolated from spent engine oil contaminated soil and used in this study.

\section{In vitro bioremediation assay}

Results of in vitro bioremediation potentials of Penicillium sp. grown on spent and unspent engine oil carried out in this study is presented in (Table 1). Results show that the growth diameter of Penicillium $s p$. inoculated on spent and unspent engine oil was $1.12 \pm 0.04 \mathrm{~cm}, 3.46 \pm 0.02 \mathrm{~cm}$, $3.57 \pm 0.05 \mathrm{~cm}, 3.67 \pm 0.01 \mathrm{~cm}, 3.69 \pm 0.03 \mathrm{~cm}, 4.08 \pm 0.02 \mathrm{~cm}, 4.50 \pm 0.04 \mathrm{~cm}$ and $0.81 \pm 0.01 \mathrm{~cm}$, $2.14 \pm 0.04 \mathrm{~cm}, 2.47 \pm 0.02 \mathrm{~cm}, 3.31 \pm 0.03 \mathrm{~cm}, 4.07 \pm 0.01 \mathrm{~cm}, 4.50 \pm 0.02 \mathrm{~cm}$ and $4.50 \pm 0.03 \mathrm{~cm}$ on the first to seventh day of incubation respectively while that of the control (Untreated) was $1.29 \pm 0.01 \mathrm{~cm}, 2.46 \pm 0.03 \mathrm{~cm}, 3.37 \pm 0.02 \mathrm{~cm}, 3.49 \pm 0.04 \mathrm{~cm}, 3.53 \pm 0.02 \mathrm{~cm}, 3.63 \pm 0.01 \mathrm{~cm}$ and $3.73 \pm 0.02 \mathrm{~cm}$ on the first to seventh day of incubation respectively. Results therefore, showed that Penicillium sp. had a significant effect $(\mathrm{p} \leq 0.05)$ in degrading the hydrocarbons present in the spent and unspent engine oil relative to control after seven days observation period. 


\section{In vivo bioremediation assay}

\section{Soil analysis}

Soil analysis revealed the presence of reasonable level of sand (20.2\%), silt (51.2\%), and Clay $(22.4 \%)$ as well as macronutrients Potassium (K) $139 \mathrm{mg} / \mathrm{kg}$, Phosphorus (P) $63 \mathrm{mg} / \mathrm{kg}$. Nitrogen $(\mathrm{N})$, organic carbon $(\mathrm{C})$, Magnesium $(\mathrm{Mg})$ and Calcium $(\mathrm{Ca})$ was $38 \mathrm{mg} / \mathrm{kg}, 1.90 \mathrm{mg} / \mathrm{kg}, 136 \mathrm{mg} / \mathrm{kg}$ and $107 \mathrm{mg} / \mathrm{kg}$ respectively. The soil $\mathrm{pH}$ was 7.2 as presented in (Table 2).

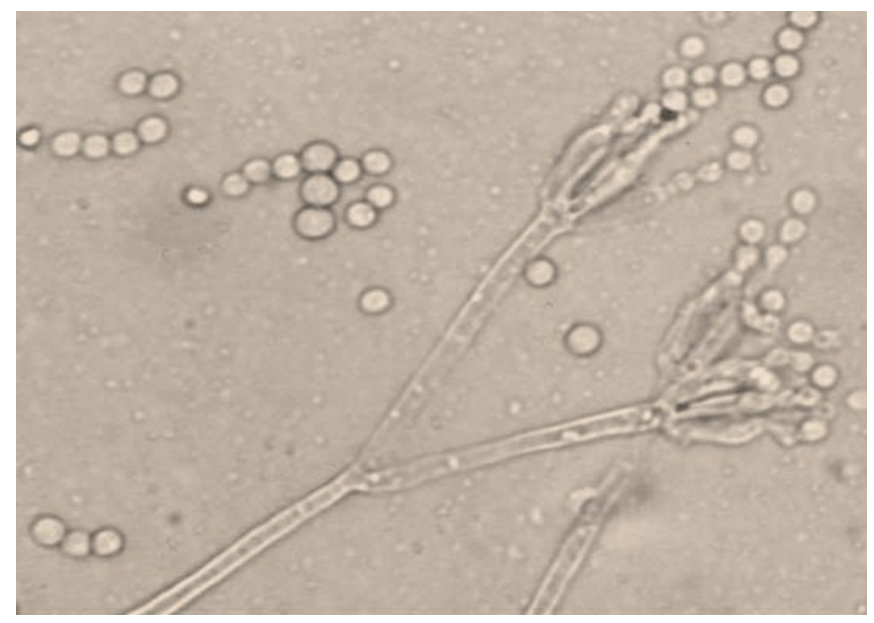

Fig. 1: Photomicrograph of Penicillium sp. $\times 40$

Table 1: Growth diameter of Penicillium sp. grown on spent and unspent engine oil for seven days $(\mathrm{cm})$

\begin{tabular}{llllllll}
\hline Treatments & \multicolumn{7}{c}{ Days of incubation and mycelium growth (cm) } \\
\hline & $\mathbf{1}$ & $\mathbf{2}$ & $\mathbf{3}$ & $\mathbf{4}$ & $\mathbf{5}$ & $\mathbf{6}$ & $\mathbf{7}$ \\
\hline $\begin{array}{l}\text { Spent } \\
\text { engine oil }\end{array}$ & $1.12 \pm 0.04$ & $3.46 \pm 0.02$ & $3.57 \pm 0.05$ & $3.67 \pm 0.01$ & $3.69 \pm 0.03$ & $4.08 \pm 0.02$ & $4.50 \pm 0.04$ \\
$\begin{array}{l}\text { Unspent } \\
\text { engine oil }\end{array}$ & $0.81 \pm 0.01$ & $2.14 \pm 0.04$ & $2.47 \pm 0.02$ & $3.31 \pm 0.03$ & $4.07 \pm 0.01$ & $4.50 \pm 0.02$ & $4.50 \pm 0.03$ \\
$\begin{array}{l}\text { Control } \\
\text { Least }\end{array}$ & $1.29 \pm 0.01$ & $2.46 \pm 0.03$ & $3.37 \pm 0.02$ & $3.49 \pm 0.04$ & $3.53 \pm 0.02$ & $3.63 \pm 0.01$ & $3.73 \pm 0.02$ \\
$\begin{array}{l}\text { Significant } \\
\text { Difference }\end{array}$ & $0.98^{*}$ & & & & & & \\
\hline
\end{tabular}

Note: $\mathrm{n}=3$; Mean \pm Standard Deviation

Table 2: Soil analysis

\begin{tabular}{ll}
\hline Soil constituents & content \\
\hline Texture (\%) & \\
\hline Sand & 20.2 \\
Silt & 51.2 \\
Clay & 22.4 \\
Soil pH & \\
pH & 7.2 \\
Nutrients (mg/kg) & \\
Potassium (K) & 139 \\
Phosphorus (P) & 63 \\
Nitrogen (N) & 38 \\
Organic carbon (C) & 1.90 \\
Magnesium (Mg) & 136 \\
Calcium (Ca) & 107 \\
\hline
\end{tabular}




\section{Bioremediation effect of Penicillium sp. on growth performance of $T$. occidentalis grown in spent engine oil contaminated soil at the different concentrations}

Growth performance of $T$. occidentalis on spent engine oil contaminated soil at the different concentrations $0 \mathrm{ml}$ (control), 20, 40,60,80, and 100mls and treatment levels with mycelium of Penicillium sp. at $20 \mathrm{ml} / 180 \mathrm{~mm}, 40 \mathrm{ml} / 360 \mathrm{~mm}, 60 \mathrm{ml} / 540 \mathrm{~mm}, 80 \mathrm{ml} / 720 \mathrm{~mm}$ and $100 \mathrm{ml} / 900 \mathrm{~mm}$ for 7, 14, 21 and 28 (DAP) is given below.

\section{Plant height (cm)}

Results of the mean plant height of $T$. occidentalis grown on spent engine oil contaminated soil at the different concentrations inoculated with mycelium of Penicillium $s p$. is presented in (Table 3). Results showed that the mean plant height of the control (untreated) $0 \mathrm{ml}(12.2 \pm 0.5) 7$ DAP was not significantly greater $(\mathrm{p}<0.05)$ than those means for plant grown in spent engine oil contaminated soil at 20/180 (13.8 \pm 0.04$), 40 / 360(13.7 \pm 0.03), 60 / 540(14.7 \pm 0.03), 80 / 720$ $(13.3 \pm 0.01)$ and $100 \mathrm{ml} / 900 \mathrm{~mm}(14.5 \pm 0.02)$ concentrations/treatments as presented in (Table 3). Results therefore, showed that there was no progressive reduction in plant height of $T$. occidentalis as the concentration of the spent engine oil increased from 20 to $100 \mathrm{ml}$. At 14 DAP; the mean plant height of the control $0 \mathrm{ml}(17.6 \pm 0.02)$ was also not significantly greater than those means for plant grown in soil at 20/180, 40/360,60/520 and $80 \mathrm{ml} / 720 \mathrm{~mm}$ concentrations/treatments except at $100 \mathrm{ml} / 900 \mathrm{~mm}(15.5 \pm 0.02)$ concentration/treatment. However, retardation of growth was not observed at this treatment level. At $21 \mathrm{DAP}$, it was observed that the mean plant height of the control $0 \mathrm{ml}(20.7 \pm 0.1)$ was also not significantly greater $(\mathrm{p}<0.05)$ than those plant grown in 20 to $80 \mathrm{ml}$ concentrations except at $100 \mathrm{ml} / 900 \mathrm{~mm}(13.5 \pm 0.02)$ concentration/treatment. At $28 \mathrm{DAP}$, it was observed that the soil became very hard and no trace of spent engine oil was observed on the surface of the soil. At 28 DAP, the growth of $T$. occidentalis initially retarded at $100 \mathrm{ml}$ concentration 21 DAP was progressive. This shows that the Penicillium $s p$. was able biodegrade the hydrocarbons which initially created a hydrophobic environment limiting water absorption through the roots. Also at 28 DAP, there was no toxic effect observed on the T. occidentalis as a result of treatment with spent engine oil, rather the $T$. occidentalis showed reasonable growth level at the different concentration/treatment levels as compared with the control. The plant began producing pods 61 DAP.

Table 3: Mean plant height of T. occidentalis grown in spent engine oil contaminated soil inoculated with mycelium of Penicillium $s p$.

\begin{tabular}{llccccc}
\hline $\begin{array}{l}\text { Concentration } \\
(\mathbf{m l}) / \text { treatment } \\
(\mathbf{m m})\end{array}$ & $\mathbf{0 ( c o n t r o l )}$ & $\mathbf{2 0} / \mathbf{1 8 0}$ & $\mathbf{4 0 / 3 6 0}$ & $\mathbf{6 0} / \mathbf{5 4 0}$ & $\mathbf{8 0} / \mathbf{7 2 0}$ & $\mathbf{1 0 0 / 9 0 0}$ \\
\hline Plant height (cm) & & & & & & \\
\hline 7 DAP & $12.2 \pm 0.5^{\mathrm{a}}$ & $13.8 \pm 0.04^{\mathrm{a}}$ & $13.1 \pm 0.04^{\mathrm{a}}$ & $14.7 \pm 0.03^{\mathrm{a}}$ & $13.5 \pm 0.01^{\mathrm{a}}$ & $14.5 \pm 0.02^{\mathrm{a}}$ \\
$14 \mathrm{DAP}$ & $17.6 \pm 0.02^{\mathrm{b}}$ & $15.7 \pm 0.03^{\mathrm{a}}$ & $15.6 \pm 0.02^{\mathrm{a}}$ & $17.4 \pm 0.2^{\mathrm{b}}$ & $14.1 \pm 0.02^{\mathrm{a}}$ & $15.5 \pm 0.02^{\mathrm{b}}$ \\
$21 \mathrm{DAP}$ & $20.7 \pm 0.1^{\mathrm{c}}$ & $19.1 \pm 0.02^{\mathrm{b}}$ & $19.1 \pm 0.04^{\mathrm{b}}$ & $18.2 \pm 0.03^{\mathrm{c}}$ & $18.8 \pm 0.1^{\mathrm{b}}$ & $13.5 \pm 0.02^{\mathrm{a}}$ \\
$28 \mathrm{DAP}$ & $22.8 \pm 0.2^{\mathrm{d}}$ & $23.2 \pm 0.1^{\mathrm{c}}$ & $21.2 \pm 0.2^{\mathrm{c}}$ & $20.1 \pm 0.01^{\mathrm{d}}$ & $19.1 \pm 0.04^{\mathrm{c}}$ & $18.2 \pm 0.5^{\mathrm{c}}$ \\
\hline
\end{tabular}

Note: ( $a, b, c$ and $d$ are subscript), Values with same subscript in the same column are not significantly different, but values with different subscript in the same column are significantly different at $(\mathrm{p}<0.05)$

\section{Leaf area (cm)}

Results of the mean leaf area of $T$. occidentalis grown on spent engine oil contaminated soil at the different concentrations inoculated with mycelium of Penicillium sp. is presented in (Table 4). Results showed that at 7 DAP, the mean leaf area of the $T$. occidentalis grown in spent engine oil contaminated soil at 20/180 (8.5 \pm 0.02$), 40 / 360(9.3 \pm 0.02), 60 / 540(7.7 \pm 0.02), 80 / 720(8.3 \pm$ $0.03)$ and $100 \mathrm{ml} / 900 \mathrm{~mm}(8.4 \pm 0.001)$ concentrations/treatments was significantly greater $(\mathrm{p}<0.05)$ than the mean leaf area of the control $0 \mathrm{ml}(5.1 \pm 0.2)$. At 7 DAP, The leaf area of $T$. occidentalis 
was observed to increase tremendously as compared to the control (Table 4). At 14 DAP; the mean leaf area of the control $0 \mathrm{ml}(10.6 \pm 0.1)$ was not significantly greater $(\mathrm{p}<0.05)$ than the mean leaf area of those plant grown on $20 / 180(10.7 \pm 0.01), 40 / 360(11.7 \pm 0.03), 60 / 540(10.3 \pm 0.01)$, $80 / 720(10.1 \pm 0.02)$ and $100 \mathrm{ml} / 900 \mathrm{~mm}(10.8 \pm 0.03)$ concentrations/treatment of spent engine oil contaminated soil. At 21 DAP; there was also no significant difference observed between the mean leaf area of the control and those plants grown on spent engine contaminated soil at the different concentrations/treatments. Leaf curl was however observed on some of the plant at higher concentrations of 80 and $100 \mathrm{mls}$. At $28 \mathrm{DAP}$, the leaf curl initially observed at 21 DAP was no longer visible. There was also no significant difference $(\mathrm{p}<0.05)$ between the control $0 \mathrm{ml}(20.1 \pm$ $0.02)$ and the plant grown on $20 / 180(19.2 \pm 0.1), 40 / 360(18.2 \pm 0.05), 60 / 520(18.1 \pm 0.02)$, $80 / 720(18.2 \pm 0.03)$ and $100 \mathrm{ml} / 900 \mathrm{~mm}(17.9 \pm 0.02)$ concentrations/treatments. Results therefore, showed that there was a reasonable increase in the mean leaf area of $T$. occidentalis as compared to the control.

Table 4: Mean leaf area of $T$. occidentalis grown in spent engine oil contaminated soil inoculated with mycelium of Penicillium $s p$.

\begin{tabular}{lllllll}
\hline $\begin{array}{l}\text { Concentration } \\
(\mathbf{m l}) / \text { treatment } \\
(\mathbf{m m})\end{array}$ & $\mathbf{0 ( c o n t r o l )}$ & $\mathbf{2 0} / \mathbf{1 8 0}$ & $\mathbf{4 0 / 3 6 0}$ & $\mathbf{6 0} / \mathbf{5 4 0}$ & $\mathbf{8 0} / 720$ & $\mathbf{1 0 0 / 9 0 0}$ \\
\hline Leaf area (cm) & & & & & & \\
\hline 7 DAP & $5.1 \pm 0.2^{\mathrm{a}}$ & $8.5 \pm 0.02^{\mathrm{a}}$ & $9.3 \pm 0.02^{\mathrm{a}}$ & $7.7 \pm 0.02^{\mathrm{a}}$ & $8.3 \pm 0.03^{\mathrm{a}}$ & $8.4 \pm 0.01^{\mathrm{a}}$ \\
$14 \mathrm{DAP}$ & $10.6 \pm 0.1^{\mathrm{b}}$ & $10.7 \pm 0.01^{\mathrm{a}}$ & $11.7 \pm 0.03^{\mathrm{b}}$ & $17.4 \pm 0.2^{\mathrm{b}}$ & $10.1 \pm 0.02^{\mathrm{a}}$ & $15.5 \pm 0.02^{\mathrm{b}}$ \\
21 DAP & $15.0 \pm 0.03^{\mathrm{c}}$ & $15.8 \pm 0.03^{\mathrm{b}}$ & $19.1 \pm 0.04^{\mathrm{c}}$ & $14.1 \pm 0.03^{\mathrm{c}}$ & $13.6 \pm 0.02^{\mathrm{b}}$ & $13.5 \pm 0.02^{\mathrm{c}}$ \\
28 DAP & $20.1 \pm 0.02^{\mathrm{d}}$ & $19.2 \pm 0.1^{\mathrm{c}}$ & $21.2 \pm 0.2^{\mathrm{d}}$ & $18.2 \pm 0.01^{\mathrm{d}}$ & $18.2 \pm 0.03^{\mathrm{c}}$ & $17.9 \pm 0.5^{\mathrm{d}}$ \\
\hline
\end{tabular}

Note: (a, b, c and d are subscript), Values with same subscript in the same column are not significantly different, but values with different subscript in the same column are significantly different at $(\mathrm{p}<0.05)$

\section{Leaf count (Number of leaves)}

Results of the mean leaf count of $T$. occidentalis grown in spent engine oil contaminated soil at the different concentrations inoculated with mycelium of Penicillium $s p$. is presented in (Table $5)$. Results showed that at 7 DAP, the mean leaf count of the T. occidentalis grown in spent engine oil contaminated soil at 20/180 $(6.0 \pm 0.03), 40 / 360(6.0 \pm 0.02), 60 / 540(6.0 \pm 0.02)$ and $80 \mathrm{ml} / 720 \mathrm{~mm}(7.0 \pm 0.02)$ concentrations/treatments was significantly greater $(\mathrm{p}<0.05)$ than the mean leaf count of the control $0 \mathrm{ml}(5.1 \pm 0.2)$ except at $100 \mathrm{ml} / 900 \mathrm{~mm} 4.0 \pm 0.02$ concentration/treatment. At $14 \mathrm{DAP}$; the mean leaf count of the control $0 \mathrm{ml}(11.0 \pm 0.02)$ was not significantly higher than those grown in 20/180 (10.7 \pm 005$), 40 / 360(10.5 \pm 0.1), 60 / 540(10.1 \pm$ $0.01)$ and $80 \mathrm{ml} / 720 \mathrm{~mm}(10.2 \pm 0.02)$ except at $100 \mathrm{ml} / 900 \mathrm{~mm}(8.2 \pm 0.03)$ concentration/treatment. However, at 21 DAP number of mean leaf count of the control $0 \mathrm{ml}(16.5 \pm 0.1)$ was not significantly higher $(\mathrm{p}<0.05)$ than those plant grown in spent engine oil contaminated soil at $20 \mathrm{ml} / 180 \mathrm{~mm}(16.0 \pm 0.2), 40 \mathrm{ml} / 360 \mathrm{~mm}(15.0 \pm 0.03), 60 \mathrm{ml} / 520 \mathrm{~mm}(15.0 \pm 0.5), 80 \mathrm{ml} / 720 \mathrm{~mm}$ $(15.3 \pm 0.02)$ and $100 \mathrm{ml} / 900 \mathrm{~mm}(15.0 \pm 0.01)$ concentrations/treatments. At $28 \mathrm{DAP}$, number of mean leaf count of the control $0 \mathrm{ml}(18.2 \pm 0.1)$ was not significantly higher than those grown in $20 / 180(18.1 \pm 0.03), 40 / 360(17.1 \pm 0.02), 60 / 520(17.7 \pm 0.2)$, and $80 \mathrm{ml} / 720 \mathrm{~mm}(17.2 \pm 0.1)$ concentrations/treatments except at $100 \mathrm{ml} / 900 \mathrm{~mm}(15.0 \pm 0.01)$ concentration/treatment level. It is noteworthy to state that at $28 \mathrm{DAP}$, the leaves of $T$. occidentalis were observed to be evergreen, this confirms that Penicillium $s p$. was able to biodegrade the hydrocarbons present in the spent engine oil contaminated soil and as such $T$. occidentalis was able to combat stomata and transpiration problems. 
Table 5: Mean leaf count of T. occidentalis grown in spent engine oil contaminated soil inoculated with mycelium of Penicillium sp.

\begin{tabular}{lllllll}
\hline $\begin{array}{l}\text { Concentration } \\
(\mathbf{m l}) / \text { treatment } \\
(\mathbf{m m})\end{array}$ & $\mathbf{0 ( c o n t r o l )}$ & $\mathbf{2 0 / 1 8 0}$ & $\mathbf{4 0 / 3 6 0}$ & $\mathbf{6 0} / \mathbf{5 4 0}$ & $\mathbf{8 0} / 720$ & $\mathbf{1 0 0 / 9 0 0}$ \\
\hline Leaf count (Number of leaves) & & & & & \\
\hline 7 DAP & $5.0 \pm 0.2^{\mathrm{a}}$ & $6.0 \pm 0.03^{\mathrm{a}}$ & $6.0 \pm 0.02^{\mathrm{a}}$ & $6.0 \pm 0.02^{\mathrm{a}}$ & $7.0 \pm 0.02^{\mathrm{a}}$ & $4.0 \pm 0.02^{\mathrm{a}}$ \\
$14 \mathrm{DAP}$ & $11.9 \pm 0.02^{\mathrm{b}}$ & $10.7 \pm 0.05^{\mathrm{b}}$ & $10.5 \pm 0.1^{\mathrm{b}}$ & $10.0 \pm 0.01^{\mathrm{b}}$ & $10.2 \pm 0.02^{\mathrm{b}}$ & $8.2^{\mathrm{a}} \pm 0.03^{\mathrm{b}}$ \\
$21 \mathrm{DAP}$ & $16.5 \pm 0.1^{\mathrm{c}}$ & $16.0 \pm 0.2^{\mathrm{c}}$ & $15.0 \pm 0.03^{\mathrm{c}}$ & $15.0 \pm 0.5^{\mathrm{c}}$ & $14.3 \pm 0.02^{\mathrm{c}}$ & $15.0 \pm 0.01^{\mathrm{c}}$ \\
$28 \mathrm{DAP}$ & $18.2 \pm 0.1^{\mathrm{d}}$ & $18.1 \pm 0.03^{\mathrm{d}}$ & $17.1 \pm 0.02^{\mathrm{d}}$ & $17.7 \pm 0.2^{\mathrm{d}}$ & $17.2 \pm 0.1^{\mathrm{c}}$ & $15.0 \pm 0.01^{\mathrm{d}}$ \\
\hline
\end{tabular}

Note: (a, b, c and $d$ are subscript), Values with same subscript in the same column are not significantly different, but values with different subscript in the same column are significantly different at $(\mathrm{p}<0.05)$

\section{Fresh weight (g) and Dry weight (g)}

Results of the mean fresh weight $(\mathrm{g})$ and dry weight $(\mathrm{g})$ of $T$. occidentalis grown in spent engine contaminated soil inoculated with mycelium of Penicillium $s p$. obtained 28 DAP is presented in (Table 6). At 28 DAP, mean Fresh weight (FW) $(\mathrm{g})$ of the control $0 \mathrm{ml}(3.60 \pm 0.01)$ was not significantly higher $(\mathrm{p}<0.05)$ than those that were grown in spent engine contaminated soil and treated with mycelium of Penicillium $s p$. at 20/180 (3.56 \pm 0.01$), 40 / 360(3.44 \pm 0.01)$ and $60 \mathrm{ml} / 540 \mathrm{~mm}(3.43 \pm 0.0) 1$ concentrations/treatments except at $80 \mathrm{ml} / 720 \mathrm{~mm}(3.30 \pm 0.01)$ and $100 \mathrm{ml} / 900 \mathrm{~mm}(3.21 \pm 0.01)$ concentration/treatment. There was however, not much progressive reduction in plant fresh weight as the concentrations/treatments of the spent engine oil increased from 20 to $100 \mathrm{ml}$ and $180 \mathrm{~mm}$ to $900 \mathrm{~mm}$ respectively. At 28 DAP, mean Dry weight (DW) (g) of the control $0 \mathrm{ml}(2.1 \pm 0.01)$ was also not significantly higher $(\mathrm{p}<0.05)$ than those plant grown on spent engine oil contaminated soil and treated with mycelium of Penicillium sp. at 20/180 (2.1 \pm $0.01), \quad 40 / 360 \quad(2.1 \pm 0.01), 60 / 540 \quad(1.9 \pm 0.01)$ and $80 \mathrm{ml} / 720 \mathrm{~mm} \quad(1.9 \pm \pm \quad 0.01)$ concentrations/treatments except at $100 \mathrm{ml} / 900 \mathrm{~mm}(1.5 \pm 0.01)$ concentration/treatment. Increase in the concentration of the spent engine oil slightly reduced the fresh and dry weight of $T$. occidentalis at the higher concentrations/treatments but showed no significant difference as compared with the control.

Table 6: Mean fresh and dry weight (g) of T. occidentalis grown in spent engine oil contaminated soil inoculated with mycelium of Penicillium $s p$.

\begin{tabular}{lll}
\hline $\begin{array}{l}\text { Concentration } \\
(\mathbf{m l}) / \text { treatment }(\mathbf{m m})\end{array}$ & FW $(\mathbf{g})$ & $\mathbf{D W}(\mathbf{g})$ \\
\hline $0($ control $)$ & $3.60 \pm 0.01^{\mathrm{a}}$ & $2.1 \pm 0.01^{\mathrm{a}}$ \\
$20 / 180$ & $3.56 \pm 0.01^{\mathrm{a}}$ & $2.1 \pm 0.01^{\mathrm{a}}$ \\
$40 / 360$ & $3.44 \pm 0.01^{\mathrm{a}}$ & $2.1 \pm 0.01^{\mathrm{a}}$ \\
$60 / 540$ & $3.43 \pm 0.01^{\mathrm{a}}$ & $1.9 \pm 0.01^{\mathrm{a}}$ \\
$80 / 720$ & $3.30 \pm 0.01^{\mathrm{b}}$ & $1.9 \pm 0.01^{\mathrm{a}}$ \\
$100 / 900$ & $3.21 \pm 0.01^{\mathrm{c}}$ & $1.5 \pm 0.01^{\mathrm{b}}$ \\
\hline
\end{tabular}

Note: ( $a, b$, c and $\mathrm{d}$ are subscript), Values with same subscript in the same column are not significantly different, but values with different subscript in the same column are significantly different at $(\mathrm{p}<0.05)$

\section{Discussion}

Spent engine oil contaminated soil is a major factor limiting the growth and yield of crops and as such effective management is critical for the profitable production of crops. In this study Penicillium sp. isolated from spent engine oil contaminated soil obtained at the Uyo Mechanic village in Afa ofot in Uyo Metropolis of Akwa Ibom State, Nigeria was studied for its ability to bioremediate spent engine oil contaminated soil at different concentrations both in vitro and in vivo. 
Authors like Mandri and Lin [19], Quinones-Aquilar et al. [20] and Bouchez et al. [21] have reported on fungi that are able to degrade various pollutants while Yateem et al. [22], Juhasz and Naidu [23], Saraswathy and Hallberg [24], Adekunle et al. [25], Atagana et al. [26], Husaini et al. [27], Gesinde et al. [28], Obire and Anyanwu [29], and Hadibarata and Tachibana [30] studied the biodegradation of petroleum products by fungi which is in conformity with this study. Soil borne fungi such as Penicillium $s p$. has been reported to produce extracellular enzymes which breakdown complex carbohydrates and as such make possible the degradation of various pollutants. Romero et al. [31] reported the ability of Penicillium $s p$. to remediate pollutants in the presence of salt which is a useful biological treatment without damage to the physically sensitive ecosystem. Penicillium sp. was used in this study to test its ability to bio-remediate spent engine oil polluted soil both in vitro and in vivo. Results of the in vitro bioremediation assay showed a significant increase $(\mathrm{p}<0.05)$ in the mycelia growth of Penicillium sp. relative to the control (Table 2) when inoculated on spent and unspent engine oil and incubated for seven days. This finding is in conformity with that of Vanishree et al. [32] who reported on the biodegradation of petrol using Penicillium sp. The increase rates of mycelia growth of Penicillium $s p$. fungus on spent and unspent engine oil in this study might have been due to the fact that the fungus utilized spent engine oil as a medium for its growth using extracellular enzymes which agrees with the work of Bartha and Atlas [33]. Researchers like Singh [34] listed some genera of fungi that were isolated from an oil polluted environment which had been demonstrated to contain members that can degrade petroleum hydrocarbons. Juhasz and Naidu [23], also mentioned some soil borne fungi such as Aspergillus and Penicillium which were found to be potential degraders of crude oil hydrocarbons while researchers like Ryan et al. [35] and Srivastava and Thakur [36] reported Fusarium solani, Fusarium oxysporum, Trichoderma viride and Aspergillus niger grown in acidic medium which also showed good growth respectively.

In this study, results of the in vivo bioremediation assay using Penicillium sp. mycelium treated spent engine oil contaminated soil at different concentrations/treatment levels of 20/180, $40 / 360,60 / 540,80 / 720$ and $100 \mathrm{ml} / 900 \mathrm{~mm}$ showed that the spent engine oil had no significant effect $(\mathrm{p}<0.05)$ on the growth performance (plant height, leaf area, leaf count (number of leaves) of T. occidentalis at 7, 14, 21 and 28 DAP and on fresh and dry weight 28 DAP when compared with the control (0ml) (Tables 3-6). The observed effect of Penicillium $s p$. treated spent engine oil contaminated soil on the growth performance of $T$. occidentalis agrees with the findings of other researchers like Adekunle et al. [25] that strains of the genus Penicillium are good hydrocarbon assimilators and that there have the ability to transform xenobiotics compounds like phenol into less mutagenic products. Workers like Pedro et al. [37] and Abdusalam et al. [38] also reported that Penicillium $s p$ has the ability to degrade monocyclic aromatic hydro carbons such as benzene, toluene, ethyl benzene and xylene; BTEX), phenol compounds and heavy metals like lead, nickel and iron using mono-oxygenases, forming a trans-diol.

\section{Conclusion}

This study showed that Penicillium sp. a soil borne fungus can biodegrade hydrocarbons present in spent engine oil and as such is a good tool for bioremediation.

\section{References}

[1] E. Dominiquez, E. Pitchel, M. Coughlin, Phytoremediation of soil contaminated with used motor oil: I. Enhanced microbial activities from laboratory and growth chamber studies, Env. Eng. Scienc. 21 (2004) 157-168.

[2] A.J. Joner et al., Priming effects on PAH degradation and ecotoxicity during phytoremediation, Exp. and Env. Pollut. 128 (2004) 429-435.

[3] P.M. White Jr. et al., Phytoremediation of alkylated polycyclic aromatic hydrocarbons in a crude oil-contaminated soil, Wat. Air. Soi. Pollut. 169 (2006) 207-220. 
[4] J. Vangronsveld et al., Phytoremediation of contaminated soils and groundwater: lessons from the field, Env. Sci. Poll. Res. 16 (2009) 765-794.

[5] L. Daane et al., Isolation and Characterization of polycyclic aromatic hydrocarbon-degrading bacteria associated with the rhizophere of soil marsh plants, Appl. Env. Microbiol. 67 (2001) 2683-2691.

[6] F.I. Achuba, B.O. Peretiemo-Clarke, Effect of spent engine oil on soil catalase and dehydrogenase activities, Int. Agrophys. 22 (2008)1-4.

[7] Z.D. Wang et al., Study of 25 year old Nipis oil spill: persistence of oil residues and comparisons between surface and subsurface sediments, Env. Sci. Technol. 32 (2000) 22222232.

[8] G.O. Anoliefo et al., Eco-taxonomic distribution of plant species around motor mechanic workshops in Asaba and Benin City, Nigeria: Identification of oil tolerant plant species, Afr. J. Biotechnol. 5 (2006) 1757-1762.

[9] S. Wei, Q. Zhou, X. Wang, Identification of weed plants excluding the uptake of heavy metals, Env. Inter. 31(2005) 829-834.

[10] V. Odjegba, A. O. Sadiq, Effects of spent engine oil on the growth parameters, chlorophyll and protein levels of Amaranthus hybridus L, The Environ. 22 (2002) 23-28.

[11] V. Meinz, Used oil characterization study. Washington state department of ecology, solid and hazardous waste programme, Hazardous waste section Olympia, Washington, 1999.

[12] B. Ikhajiagbe, G.O. Anoliefo, Natural attenuation of a 14-month-old spent engine oil polluted soil, J. Soil Sci. Env. Manag. 2 (2011) 184-192.

[13] J.C. Fetzer, The chemistry and analysis of large polycyclic aromatic hydrocarbon, Wiley and Son Company, New York, 2000.

[14] H.L. Barnett, B.B. Hunter, Illustrated genera of imperfect fungi fourth ed., APS Press, St Paul Minnesota, 1998.

[15] R. Thenmozhi et al., Studies on Mycoremediation of used engine oil contaminated soil samples, Adv. Appl. Sci. Res. 4 (2013) 110-118.

[16] J.C. Yeoman's, J.M. Bremner, A rapid and precise method for routine determination of organic carbon in soil, Communications in Soil Science and Plant Analysis. 19 (1989) 14671476.

[17] J. Murphy, J.J.P. Riley, A modified single selection method for determination of phosphate in natural water, Anal. Chem. Acta. 27 (1972) 31-36.

[18] A.A. Adekunle, O.A. Adebambo, Petroleum hydrocarbon utilization by fungi isolated from Detarium Senegalense (J. F Gmelin) Seeds, J. Amer. Sci. 3 (2007) 25-31.

[19] T. Mandri, J. Lin, Isolation and characterization of engine oil degrading indigenous microorganisms in Kwazulu-Natal, Afr. J. Biotechnol. 6 (2007) 23-27.

[20] E.E. Quinones-Aquilar et al., Emergence and growth of maize in a crude oil polluted soil, Agroc. 37 (2003) 585-594.

[21] M. Bouchez et al., Les hydrocarbures aromatiques polycycliques dans l'environnement. Deuxieme partie: La degradation par voie microbienne, polycyclic aromatic hydrocarbons in the environment Part two: Microbial degradation of oil and gas, Sci. Technol. 51 (1996) $797-$ 828.

[22] A. Yateem, M.T. Balba, N. Al-Awadhi, White rot fungi and their role in remediating oil contaminated soil, Env. Inter. 24 (1998) 181-187.

[23] A.L. Juhasz, R. Naidu, Bioremediation of high molecular weight polycyclic aromatic hydrocarbons: A review of the microbial degradation of benzo[a]pyrene, Int. J. Biod. Biodegrad. 45 (2000) 57-88.

[24] A. Saraswathy, R. Hallberg, Degradation of pyrene by indigenous fungi from a former gasworks site, FEMS Microbiol. Let. 210 (2002) 227-232.

[25] A.A. Adekunle, P.O. Uaboi-Egbenni, T. Ajayi, Biodegradation of petroleum products by Saccharomyces cerevisea, Nig. J. Bot. 17 (2004) 83-94. 
[26] H.I. Atagana, R.J. Haynes, F.M. Wallis, Fungal bioremediation of creosote-contaminated soil: A laboratory scale bioremediation study using indigenous soil fungi, Water, air, and soil pollution. 172(1-4) (2006) 201-219.

[27] A. Husaini et al., Biodegradation of aliphatic hydrocarbon by indigenous fungi isolated from used motor oil contaminated sites, World Journal of Microbiology and Biotechnology. 24(12) (2008) 2789-2797.

[28] A.F. Gesinde et al., Bioremediation of some Nigeria and Arabian crude oils by fungal isolates, International Journal of Pure and Applied Sciences. 2(3) (2008) 37-44.

[29] O. Obire, E.C. Anyanwu, Impact of various concentrations of crude oil on fungal populations of soil, Int. J. Env. Sci. Technol. 6 (2009) 211-218.

[30] T. Hadibarata, S. Tachibana, Microbial Degradation of n-Eicosane by filamentous fungi. In: Interdisciplinary studies on environmental chemistry: Environmental research in Asia, Eds. Y. Obayashi et al., Terrapub, Tokyo, 2009, pp. 323-329.

[31] C.H. Romero et al., Benzo[a]pyrene degradation by soil filamentous fungi, Journal of Yeast and Fungal Research. 1(2) (2010) 25-29.

[32] M. Vanishree, A.J. Thatheyus, D. Ramya, Biodegradation of petrol using the fungus Penicillium sp., Sci. Inter. 2 (2014) 26-31.

[33] R. Bartha, R.M. Atlas, The Microbiology of Aquatic oil spills, Adv. Appl. Microbiol. 22 (1997) 225-266.

[34] H. Singh, Mycoremediation: Fungal Bioremediation, Wiley-Interscience, New York, 2006.

[35] D.W. Ryan, E. Leukes, S. Burton, Improving the bioremediation of phenolic wastewaters by Trametes versicolor, Biores. Technol. 98 (2007) 579-587.

[36] S. Srivastava, I.S. Thakur, Evaluation of bioremediation and detoxification potentiality of Aspergillus niger for removal of hexavalent chromium in soil microcosm, Soil Biology and Biochemistry. 38 (2006) 1904-1911.

[37] P. Pereira et al., DNA damage induced by hydroquinone can be prevented by fungal detoxification, Toxicology Reports. 1 (2014) 1096-1105.

[38] S. Abdulsalam et al., Bioremediation of soil contaminated with used motor oil in a closed system, Biorem. Biodeg. 3 (2013) 100-172. 